\title{
Make an Honorary Board of Election Organizers (DKPP) as a Special Election Justice
}

\author{
Rokiyah $^{1} \quad$ M. Iwan Satriawan ${ }^{2} \quad$ Shohib Muslim $^{3}$ \\ 1. Lecturer at Politeknik Negeri Malang \\ 2. Lecturer at Faculty of Law, Lampung University \\ 3. Lecture at Politeknik Negeri Malang
}

\begin{abstract}
General elections (elections) in Indonesia have their own dynamics. Starting from the institutional organizers to the dispute resolution institutions of election results. This can not be separated from every moment of the election, both central and regional (pilkada), which always presents various kinds of claims because of the emergence of fraud and election violations both intentionally and because of mistakes. So far, the official electoral dispute resolution institutions concerning election crimes are in the general court under the Supreme Court. If it concerns the election results in the Constitutional Court, if it concerns the decision of the election organizers in the State Administrative Court. And if it concerns the ethics of the election organizers on the election executive board (DKPP). While the Bawaslu itself according to Law No.7 of 2017 concerning elections resolves disputes over electoral violations outside the criminal aspect. This has caused the ineffectiveness of the electoral court.This study aims to identify, understand and analyze legal certainty and justice in elections, especially DKPP as a special election court. So that the principle of justice in elections is obtained by the public. The research is a normative study using several approaches, namely legislation approach, case approach, and comparative approach. The results of this review revealed that efforts to realize special election justice became important. There is still debate between the choice of submitting a new institution or turning an existing institution into an election justice institution. Likewise, between making the ad hoc or permanent electoral institutions under the Supreme Court still in the study stage. Then it is necessary to redesign the institutions that have the authority to settle the election results and regional elections that must be carried out without creating a new institution but utilizing the existing EMB.
\end{abstract}

Keywords: Elections, Special Election Courts, DKPP.

DOI: $10.7176 / J L P G / 83-10$

Publication date:March $31^{\text {st }} 2019$

\section{Introduction}

Conceptual elections are a means of implementing people's sovereignty. Through elections the legitimacy of people's power is implemented through the surrender of some of their power and rights to their representatives in parliament and government. With this mechanism, at any time people can hold the government accountable for power ${ }^{1}$.

Likewise with the Unitary Republic of Indonesia (NKRI). As a country that has just escaped from the grip of an authoritarian regime towards democracy, realizing an honest and fair election (jurdil) becomes a necessity. This is because during the New Order era although regular elections were held every 5 (five) years but long before the vote count was carried out the election winners were predictable.

So the 1998 reform was the door to the future changes in democracy whether Indonesia would become a democratic country or even fall deeper into the oligarchic and plutocratic countries.

The 1998 reform did not only replace the ruler from Soeharto to B.J Habibie, but also changed the government order from despotic to democratic. One of them is through the implementation of elections both at the center ${ }^{2}$ and area $^{3}$ jurdil (honest and fair) and overflowing (direct public free of secrets) as mandated by law.

Because even though the election slogan in the new order era was overflowing (direct general freedom and secrecy), it was only black and white which was not in accordance with the implementation in the field. This was then referred to as pseudeo democracy, in the sense that formally democracy had been carried out, but materially many violations and fraud in it which were silenced even became a necessity to be realized by involving the state civil apparatus (ASN) and ABRI.

This implies that Suharto was able to take power as an Indonesian President for 32 years and Golkar from the first election in the New Order era to the last, namely in 1997 he was in power in parliament with more than $50 \%$ of seats so when voting was decided to accept or reject executive policy, Golkar as the party that stands for the government in parliament always wins and executive policy also strides without obstruction by the

\footnotetext{
${ }^{1}$ Fajlurrahman Jurdi, Pengantar Hukum Pemilihan Umum, Jakarta: Kencana Prenada media, 2018, pp.1

${ }^{2}$ The presidential election was held directly in 2004.

${ }^{3}$ The regional election which was originally chosen by the DPRD then through Law No. 32 of 2004 was carried out directly in 2005.
} 
parliament.

Then the application of democracy in various countries in the world, has its own characteristics and specifications, which are usually very influenced by the conditions and social, economic, cultural and political developments of the people in a country. Therefore the form of democracy in a country should pay attention to the traditional values, social, economic and local political potential of the country concerned ${ }^{1}$.

Even some observers claim that democracy is now experiencing stagnisation, erosion and even recession. So it is not surprising that a view arises that states that if democracy is not right applied throughout the world, especially the failure of the Arab Spring to bring democracy. In addition to the incompatibility between culture and democracy, some assess the location of the retreat of democracy because the focus of democracy is always talking about elections and not on other essential features of democracy ${ }^{2}$.

Because in fact the essence of democracy is that welfare and justice for all people is not only the goal. Democracy is only a tool towards a state of welfare and justice. This is not inseparable in a democratic country every citizen is given the same opportunity to serve the state and also the limitation of power to avoid the use of power by the authorities. As stated by Lord Acton "Power tends to be corrupt, and absolute power is corrupts absolutely".

The form of limitation of power is through the implementation of elections in several countries experiencing a time difference. There are once every 4 (four) years such as the Philippines and the United States, but there are also those every 5 (five) years like Indonesia. Even in some countries, it is also added that if they have been elected for 2 (two) consecutive times, they should not nominate for the third time so that they can provide opportunities for other citizens to participate in developing the country either through running for regional heads or heads of state .

To realize overlapping and fair elections not only seen from the aspect of the organizers, but also more important in the aspect of law enforcement. Because starting from the 1955 elections until the last 2018 regional election there was no clean election. Always overgrown with the practices of violations and electoral crimes both committed by election organizers such as the KPU and Bawaslu until election participants through their disappointed success team lost in the regional elections in particular.

\section{Research Method}

This type of research is normative legal research which is a study in the context of the field of law to be able to examine the substance of positive law that exists textually which is not only about norms, but also principles even the values contained in it are related to elections. The research approach used is the legislative approach, conceptual approach and comparative approach. A legal approach is needed to further examine the legal basis. The legal approach is carried out by examining all laws and regulations relating to legal issues. ${ }^{3}$ Conceptual approach, departs from views and doctrines that develop in law. ${ }^{4}$ Study these views and doctrines by interpreting systematization of written legal material. Whereas the comparison approach is one of the methods used in normative research to compare one legal institution (legal institution) and one legal system with legal institutions (which is more or less the same as the legal system) in the other.

Collecting data in this study by conducting library searches in the form of data in the form of primary and secondary legal materials that are relevant to the topic of the problem that has been formulated into one unit and classification according to sources and hierarchies to be comprehensively studied The sources of legal material used in this study are primary legal material and secondary legal material. Primary legal material is legal material that is authoritative, meaning having authority. Primary legal materials consist of laws and regulations that are sorted by hierarchy. ${ }^{5}$ While secondary legal materials, are legal materials obtained through library studies, in the form of: books, journals, magazines, media articles and various other sources that support this writing obtained through the internet. Case studies will be used to complement the sources of primary and secondary legal materials.

Legal material obtained through library research studies is analyzed critically by using theories and legal principles systematically and coherently to obtain answers to the problems carried out in this study. The results of the analysis of the legal materials are expected to be able to answer the problem and provide an overview of the law on the implementation of elections and efforts to realize the special election court. Further said in conducting legal research the steps taken are as follows: ${ }^{6}$

1) Identifying legal facts and eliminating irrelevant matters to establish legal issues that are to be resolved;

\footnotetext{
${ }^{1}$ Ratnia Solihah, Demokrasi Lokal di Indonesia dalam Perspektif Ekonomi Politik, Journal of Ethics and Elections, Vol.1, Number 3 October 2015, p.77.

${ }^{2}$ Fritz Edward Siregar, Bawaslu Menuju Peradilan Pemilu, Jakarta, Themis Publishing,2018, p.2-3.

${ }^{3}$ Peter Mahmud Marzuki, Penelitian Hukum, Jakarta: Kencana Prenada Media Group, 2005, p. 171.

${ }^{4}$ Ibid hlm.7.

${ }^{5}$ Ibid hlm.141.

${ }^{6}$ Ibid.
} 
2) Collection of legal materials and if deemed to have relevance also non-legal materials;

3) Reviewing the issues raised based on the materials that have been collected;

4) Draw conclusions in the form of arguments that answer legal issues.

5) Give prescriptions based on arguments that have been built in conclusions.

\section{Results And Discussion \\ State Institution}

State institutions (state organs) or state bodies are nomenclature given to bearers of functions in the system of state administration, which must work together in achieving the stated objectives. ${ }^{1}$ Actually, in simple terms the state organs or state institutions can be distinguished from the words of private organs or institutions, community institutions, or commonly called NGOs or Non-Governmental Organizations which in English are called NonGovernment Organizations or Non-Governmental Organizations (NGO's). Therefore, any institution formed not as a community institution can we call a state institution. State institutions can be in the domain of the legislative, executive, judiciary and mixed nature. ${ }^{2}$

The word institution in practice is used in many meanings or meanings. As a synonym, institutions are also intended to have the same meaning as the institution. There is also an institution that equates with the word pranata, because it is known as a democratic institution, a marriage institution, a pre-trial institution and others. On the other hand, the institution also intended its understanding to be the same as the organization or agency and from this understanding the names of the Indonesian Institute of Sciences (LIPI), the National Land Agency (Lemhanas) were known. ${ }^{3}$

The state institution itself is a government institution or "civilizated organization" where the institution is created by the state, from the state, and for the state which aims to develop the country itself ${ }^{4}$. In Dutch the conception of state institutions is called staatsorgaan, while the English literature is called Political Instruction, whereas in the Big Indonesian Dictionary (KBBI 1997), the word institution is defined as (i) origin or will (which will become something); (ii ) original form (appearance, form); (iii) reference, bond; (iv) body or organization that aims to conduct scientific inquiry or conduct a business; and (v) established behavior patterns consisting of structured social interactions. ${ }^{5}$

State institutions are sometimes referred to as government institutions, non-departmental government agencies or state institutions only. Some are formed based on or because they are given power by the Constitution, some are formed and get their power from the Law, and some are even formed based on the President's decision. Hierarchy or ranking of course depends on the degree of regulation according to applicable legislation. ${ }^{6}$

To understand the definition of state institutions or organs more deeply, we can find in Hans Kelsen's view of the concept of the State Organ in his book General Theory of Law and State. Hans Kelsen describes that "Whoever fulfills a function determined by the legal order is an organ" means that anyone who performs a function determined by a legal order is an organ. ${ }^{7}$

But in the context of Indonesian constitution according to Lukman Hakim in his book the Legal Position of the State Commission in Indonesia states that there is no clear understanding of state institutions. ${ }^{8}$ This then requires a further explanation of the state institutions, including the conditions for establishing a commission, whether it is ad hoc or permanent, there is also a similar standard mechanism in determining and selecting commission members and also how the accountability mechanism. ${ }^{9}$

Indonesia itself after the amendment to the 1945 Constitution has abolished the highest state institution. So that what is in Indonesia is a high state institution, a state institution and an independent institution whose degree of existence depends on whether it is ordered by the 1945 Constitution such as the President, Vice President, House of Representatives, Regional Representatives, Audit Board, Supreme Court and Constitutional Court. Or because it was ordered by law alone such as the National Commission on Human Rights, Election Administration Agency, Election Organizing Board of Honor, Information Commission, Indonesian

${ }^{1}$ Fimansyah dkk, Lembaga Negara dan Sengketa Kewenangan Antar lembaga negara, Jakarta:KRHN,2005.p.15.

${ }^{2}$ Jimly Asshiddiqie ,Perkembangan dan Konsolidasi Lembaga Negara Pasca Reformasi, Jakarta:Konstitusi Pers,2006,p.31.

${ }^{3}$ Lukman Hakim, ,Kedudukan Hukum Komisi Negara di Indonesia, Malang:PPS Unibraw,2010,p.155.

${ }^{4} \mathrm{http}$ ://id.wikipedia.org/wiki/Lembaga negara,diakses accessed on 25 August 2011.

5 Jimly Asshiddiqie,Op.cit.,p.31.

${ }^{6}$ Ibid.,p.43.

${ }^{7} \mathrm{http}: / /$ kanekzoke.blogspot.com/diakses on September 19, 2011 page 1.

${ }^{8}$ Furthermore it was stated that the lack of clarity regarding the definition of state institutions requires absolute clarity so that it has clear bases and criteria for an institution that can be classified as a state institution. Besides that, it is also necessary to re-arrange whether the existence of the commission is effective in the context of legal reform in Indonesia and must be placed in the context of the R.I.,op.cit.,p.6.

${ }^{9}$ Regarding this see more specifically in Chapter VII A Article 23 F, and Article 23 G of the Financial Audit Agency (BPK) and Article 24 C paragraph (1) of the 1945 Constitution concerning one form of the Constitutional Court's authority to examine and decide disputes between State Institutions whose authority is granted by the 1945 Constitution. 
Broadcasting Commission and Ombudsman.

\section{he Honorary Board of Election Organizers (DKPP)}

The election management structure has historically been regulated by Law No.12 of 2003 concerning elections, namely by the existence of an ethical institution that is ad hoc in nature and can only be formed by the KPU. In the following period based on Law No.22 of 2007, the Election Commission (DK KPU) and the Honorary Board of The Election Supervisory Agency (DK Bawaslu) were formed and were ad hoc.

Then through Law No. 15 of 2011 a Permanent Election Organizing Council (DKPP) was formed which has the authority to maintain the ethical status of the election organizers. DKPP is given the authority to examine and decide complaints and / or reports of alleged ethical violations committed by the election organizer. DKPP is located in the national capital and its members consist of one element of Bawaslu, one element of the KPU and 5 (five) community leaders. The DKPP members who came from community leaders, were nominated by the president as many as 2 (two) people and by the DPR as many as 3 (three) people.

As an ethical judiciary for independent election organizers, DKPP has resolved complaints of ethical violations committed by state administrators. Based on data from June 2012 to 31 December 2014, DKPP received complaints of 561 cases with details in 2012 receiving complaints of 99 cases, in 2013 as many as 577 cases, and in 2014 as many as 885 complaints $^{1}$.

Entering simultaneous electoral preparations in 2019, Law No.15 of 2011 is replaced with Law No.7 of 2017 concerning Elections where DKPP's authority does not change, namely resolving ethical violations committed by election organizers namely KPU and Bawaslu.

On the other hand for 2018 from January 1 to December 1, 2018, DKPP has received 333 complaints, with monthly recapitulation as shown in the graph below:

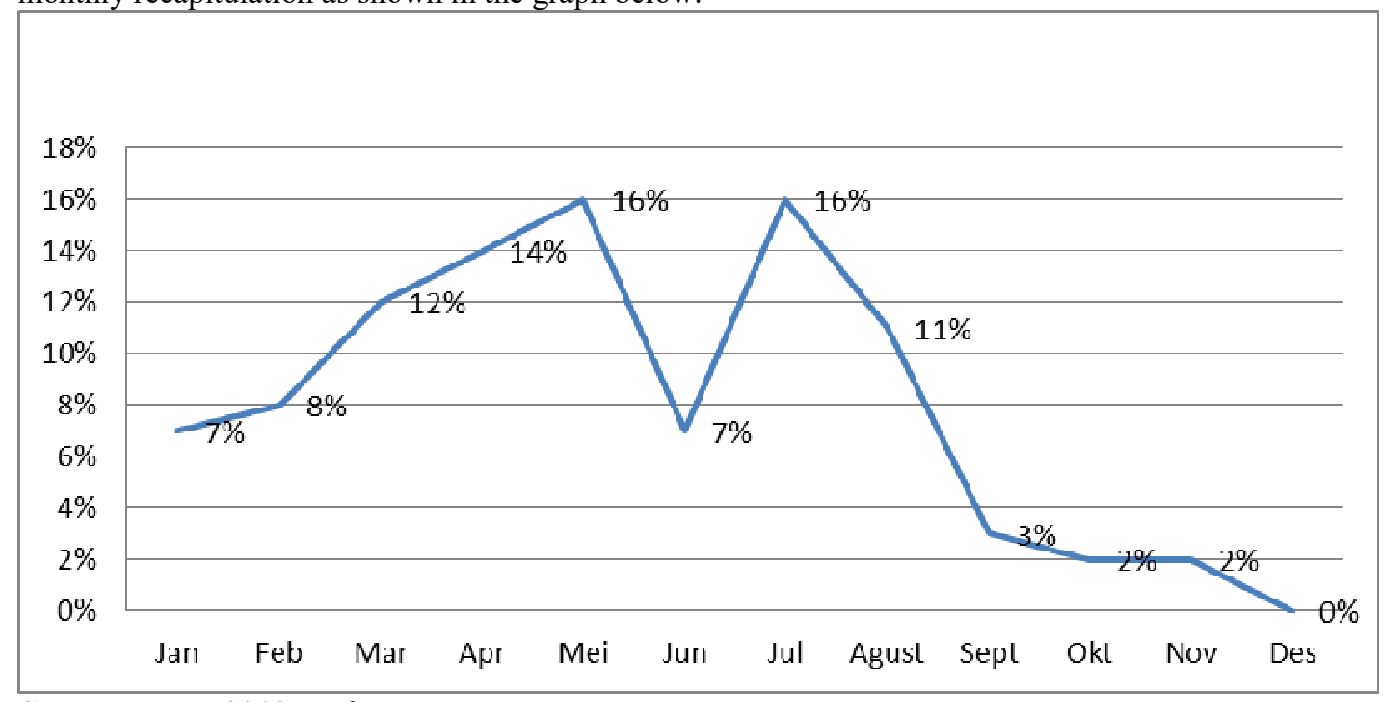

Source: DKPP 2018 Performance Report

The number of reports from April to August is related to the implementation of simultaneous regional elections in 2018 in 17 provinces, 39 cities and 115 regencies throughout Indonesia. This shows that the election ethics is still weak due to the lack of quality of human resources and the recruitment process of election organizers that are still influenced by the role of political parties in it.

\section{The Election Supervisory Agency (Bawaslu)}

In 1982 a General Election Implementation Supervisory Committee was formed (Election Panwaslak) in accordance with the mandate of Law Number 2 of 1980 in lieu of Law Number 4 of 1975. The emergence of the Election Panwaslak was due to the completion of the Indonesian Democratic Party and the united development Party regarding the number of violations elections in 1977. However, in this law no oversight mechanism was explained. It is precisely the oversight mechanism submitted to government regulations that in fact are never honest and independent. Over time, at the end of 1984, for the third time the government proposed a change to the election law. This proposal was accepted by the House of Representatives so that on 7 January 1985 Law No. 1 of 1985 was enacted concerning Amendment to Law Number 15 of 1969 concerning General Elections of Members of the Consultative Body / People's Representatives as amended by Law Number 4 Year 1975 and

\footnotetext{
${ }^{1}$ M.Risnain, Kelembagaan Mahkamah Etik Penyelenggara Negara, Journal of Ethics and Elections, Volume 1 Number 1 of 2015, p.39.
} 
Law No. 2 of 1980 (Law No. 1/1985).

The various changes to the law on elections in the New Order era did not substantially change the general election mechanism. The amendment to the law only adapts to existing conditions in the region and to further legalize Golkar's dominance in every election in Indonesia.

Then learn from the experience of holding elections in the New Order era and based on existing developments in the community, especially after the amendments to the 1945 Constitution. So the General Election Commission as the only organ of election management is considered to have shortcomings so that a new institution is needed to help the performance of the General Election Commission. Starting from the issuance of the General Election Commission Decree No. 88 of 2003 concerning Supervisory Committee (election supervision). Then the existence of the Supervisory Committee was evaluated and ensured with the establishment of the Election Supervisory Agency (BAWASLU). The Election Supervisory Agency (BAWASLU) is one of the election management institutions which was established permanently in 2009 because of the mandate of Law No.22 of 2007 concerning the Implementation of General Elections. Although in fact in 1997 it had been endeavored to establish an Independent Election Monitoring Committee (KIPP), but it had not run optimally due to the repressive actions of the new order government. The existence of BAWASLU itself cannot be separated from the importance of the supervision mechanism for the realization of quality elections.

Similar to the General Election Commission, the results of the 2004 election evaluation encouraged the government and legislative bodies to organize the election supervisory institutions through Law No.22 of 2007 . In this law, election supervisors received special attention, namely apart from the name and institutional nature. the former election supervisors were ad hoc, changed to Bawaslu as a permanent institution at the central level, as well as strengthening on the side of institutional authority ${ }^{1}$.

\section{DKPP As Election Court}

The trial of the results of general elections (elections) in Indonesia was born after a change in the 1945 Constitution of the Republic of Indonesia (UUD 1945). Article 24C Paragraph (1) of the 1945 Constitution gives authority to the Constitutional Court (MK) as a judicial institution that decides disputes or disputes over election results both the legislature (People's Representative Council, Regional Representative Council, Regional Representative Council) and the Presidential and Vice-President elections. In its development, the authority of the Constitutional Court to adjudicate disputes over election results has expanded, including also disputes over the results of regional head elections (pilkada) since the transfer of authority to try from the Supreme Court ${ }^{2}$.

The entry of the Constitutional Court as a judicial institution that has the authority to decide on electoral disputes has made the Constitutional Court in the political court because elections are very close to politics. The phenomenon of judicialization of politics can be said to be something that is common in a constitutional democratic country, but there are not a few who are sekeptis towards the phenomenon and criticize it because with the inclusion of political cases, the court will use political considerations in taking In his writing, Jonghyun Park stated in his writing that the judicialization of politics phenomenon could destroy the values of the rule of law $(\text { rule of law })^{3}$.

The fact is that this additional burden has a very real impact on the energy drained by the judges of the Constitutional Court, so that the implementation of the authority to examine laws against the 1945 Constitution seems to be "defeated" by the implementation of electoral dispute resolution powers both presidential, legislative and regional head elections.

Based on data that has existed since the transfer of authority to decide disputes on post-conflict local elections from 2008 to mid-August 2013, the Constitutional Court has decided 598 applications. Whereas since simultaneous post-conflict local elections in 2015, the Constitutional Court has received 88 disputes and in 2017 the Constitutional Court received 49 disputes so that the total since the simultaneous post-conflict local election was implemented, the Constitutional Court has received 137 post-conflict local election disputes. As for testing the law, in 2016 the Constitutional Court accepted 111 requests for judicial review coupled with the remaining cases in 2015 totaling 63 cases resulting in a total of 174 judicial reviews throughout 2016 . Another impact and not less important is the dragging of several Constitutional Court judges to cases of violations of the code of ethics ${ }^{4}$ and bribery ${ }^{5}$ cases involving participants or contestants in post-conflict local elections.

\footnotetext{
${ }^{1}$ Topo Santoso dan Ida Budhiarti, Pemilu di Indonesia (Kelembagaan, Pelaksanaan dan Pengawasan),Jakarta:Sinar Grafika,2019,p.195

${ }^{2}$ Heru Widodo, Hukum Acara Sengketa Pemilukada (Dinamika Di Mahkamah Konstitusi),Jakarta:Konstitusi Press,2018,p.1

${ }^{3}$ Abdurrahman Satrio, Kewenangan Mahkamah Konstitusi Memutus Perselisihan Hasil Pemilu Sebagai Bentuk Judicialization of Politics, Journal of the Constitution, Volume 12 Number 1 March 2015, p.125, Mahkamah konstitusi:Jakarta

${ }^{4}$ The Arsyad Sanusi case is considered to violate the code of ethics because there are family members who are in contact with parties who are in a state where one of the judges is Arsyad Sanusi. Read on http://www.hukumonline.com/berita/baca/lt4d54dda21b2c0/hakim-arsyadterbukti-langgar-kode-etik, accessed on 9 October 2017 at 16.45 WIB.

${ }_{5}^{5}$ Akil Mochtar's case with the Supreme Court's decision No. 336 K / Pid.Sus / 2015 while the Akbar Patrilialist case read on http://nasional.kompas.com/read/2017/09/12/10124921/patrialis-akbar-tidak-ajukan-banding-atas-vonis-8-tahun-penjara. accessed on 9
} 
Re-conceptualizing or rearranging the concept of dispute resolution on election results, is intended to find alternative solutions to resolving disputes over election results that can provide a sense of legal certainty, justice and benefit for the disputing parties or other related parties. ${ }^{1}$

So separating the election disputes from the Constitutional Court is a necessity in order to maintain the spirit of the Constitutional Court which initially aimed to examine laws against the 1945 Constitution, disputes between state institutions, dissolution of political parties and test the impeachment of the People's Representative Council for the president. Because as long as the dispute over election results is put on the Constitutional Court the Constitutional Court's decision can be guessed between a recount or a repeat trial in regions or regions that have a significant influence on the change of voice between candidates.

While in the form of data, the majority of countries in the world, which amounted to $59 \%$ or as many as 132 countries, gave the authority to settle disputes with the judiciary. While $37 \%$ or as many as 84 countries implemented dispute resolution by EMBs, including Indonesia ${ }^{2}$.

Based on this, the authors offer the establishment of special institutions for resolving electoral disputes both at the center and the regions. This phenomenon is related to the importance of electoral justice not only for participants but also for the voting community.

So letting go of the electoral justice from the election organizers is a very urgent need. This is aimed at making electoral judges more focused in resolving electoral disputes both in the presidential election, People's Representative Council, Regional Representative Council, Regional Representative Council and regional heads.

Within the judiciary, to date there have been at least eight special courts under the public, religious and administrative courts, namely: juvenile justice, commercial courts, human rights courts, corruption courts, industrial relations courts, fisheries courts, sharia court and tax court. The first six types of courts are courts that are in the general court environment, while the last two types of courts are within the religious court and state administrative courts ${ }^{3}$.

One form is to make DKPP a special election court that is permanent from the center to the regions. Because all this time the DKPP has run the ethics court of the election organizers, whose position will be replaced by an ethics council in each of the electoral institutions whose existence is only in the center. Why isn't the Election Supervisory Body (Bawaslu) being used as an election judiciary? according to the author if the bawaslu is transformed into an electoral justice institution while election oversight is left to non-governmental organizations as a manifestation of participatory supervision it will be very vulnerable to a lawsuit for an election dispute by NGOs or the general public.

By continuing to make the Election Supervisory Body (Bawaslu) as an election supervisory institution, it still positions the Election Supervisory Body (Bawaslu) as a prosecutor's office which is a public prosecutor. So that there are still efforts for people who have difficulty resolving electoral disputes through lawyers or themselves can report and be accommodated by the Election Supervisory Board. This is related to the condition of the Indonesian people's democratic index that is not yet good, so that it still needs official state institutions, namely the bawaslu to participate in supervising the implementation of the election.

This can be seen in the Indonesian Democracy Index (IDI) in 2017 which reached 72.11 on a scale of 0 to 100. This number has increased compared to the IDI 2016 figure of 70.09. The achievements of Indonesia's democratic performance are still in the "moderate" category. The classification of the level of democracy itself is grouped into three categories, namely "good" (index> 80), "moderate" (index 60-80), and "bad" (index $<60$ ) ${ }^{4}$.

\section{Conclusions}

Separating the dispute over the election results from the Constitutional Court is an option that must be done immediately in order to maintain the authority of the Constitutional Court as the highest institution that specifically hears the testing of laws against the Constitution, dissolution of political parties, disputes over authority between state institutions and alleged violations of the president by the DPR. This is related to the fact that the ruling on the results of the election at the Constitutional Court cannot be separated from the recalculation or repeated trial if the exact request is received by the Constitutional Court.

Then redesigning institutions that have the authority to settle election results and regional elections must be done without creating a new institution but utilizing the existing EMB. The author tends to make DKPP an electoral justice institution related to the DKPP so far that it has functioned as an ethics institution for election management.

October 2017 at 16.45 WIB.

${ }^{1}$ Jayus, Rekonseptualisasi Penyelesaian Perselisihan Haisl Pemilihan Umum di Indonesia, Journal of the Constitution, Volume 10, Number 2 June 2013, p.226.

${ }^{2}$ Fritz Edward Siregar, Op.Cit,p.65

${ }^{3}$ Refli Harun, Rekontruksi Kewenangan Penyelesaian Perselisihan hasil Pemilihan Umum, Journal of the Constitution, Volume 13 Number 1 March 2016, p.14.

${ }^{4}$ Ibid. 
Reference

Abdurrahman Satrio, Kewenangan Mahkamah Konstitusi Memutus Perselisihan Hasil Pemilu Sebagai Bentuk Judicialization of Politics, Journal of the Constitution, Volume 12 Number 1 March 2015.

Fimansyah dkk, Lembaga Negara dan Sengketa Kewenangan Antar lembaga negara, (Jakarta, KRHN, 2005).

Fritz Edward Siregar, Bawaslu Menuju Peradilan Pemilu, (Jakarta, Themis Publishing, 2018).

Fajlurrahman Jurdi, Pengantar Hukum Pemilihan Umum, (Jakarta, Kencana Prenada media, 2018).

Heru Widodo, Hukum Acara Sengketa Pemilukada (Dinamika Di Mahkamah Konstitusi), (Jakarta, Konstitusi Press, 2018).

Jayus, Rekonseptualisasi Penyelesaian Perselisihan Haisl Pemilihan Umum di Indonesia, Journal of the Constitution, Volume 10, Number 2 June 2013.

Jimly Asshiddiqie ,Perkembangan dan Konsolidasi Lembaga Negara Pasca Reformasi, (Jakarta, Konstitusi Pers, 2006).

Lukman Hakim, ,Kedudukan Hukum Komisi Negara di Indonesia, (Malang, PPS Unibraw, 2010).

M. Risnain, Kelembagaan Mahkamah Etik Penyelenggara Negara, Ethics and Election Journal, Volume 1 Number 1 of 2015.

Peter Mahmud Marzuki, Penelitian Hukum, (Jakarta, Kencana Prenada Media Group, 2005).

Ratnia Solihah, Demokrasi Lokal di Indonesia dalam Perspektif Ekonomi Politik, Ethics and Election Journal, Vol.1 Number 3 October 2015.

Refli Harun, Rekontruksi Kewenangan Penyelesaian Perselisihan hasil Pemilihan Umum, Journal of the Constitution, Volume 13 Number 1 March 2016.

Topo Santoso dan Ida Budhiarti, Pemilu di Indonesia (Kelembagaan, Pelaksanaan dan Pengawasan), (Jakarta, Sinar Grafika, 2019).

Laws and Regulations

1945 Constitution of the Republic of Indonesia.

Law No.12 of 2003 concerning General Elections of Members of the House of Representatives, Regional Representative Council, and Regional Representative Council.

Law No.22 of 2007 concerning general election organizers.

Law No.15 of 2011 concerning general election organizers

Law Number 1 of 1985 concerning Amendment to Law Number 15 of 1969 concerning General Elections of Members of the Consultative Body / People's Representatives as amended by Act Number 4 of 1975 and Law Number 2 of 1980 (Law No 1/1985).

Decision of the General Election Commission number 88 of 2003 concerning the Election Supervisory Committee. 